\title{
The Silk Road in World History: A Review Essay
}

\author{
Alfred J. ANDREA \\ University of Vermont \\ Burlington, Vermont USA \\ aandrea@uvm.edu
}

\begin{abstract}
The Silk Road, a trans-Eurasian network of trade routes connecting East and Southeast Asia to Central Asia, India, Southwest Asia, the Mediterranean, and northern Europe, which flourished from roughly 100 BCE to around 1450, has enjoyed two modern eras of intense academic study. The first spanned a period of little more than five decades, from the late nineteenth century into the early193os, when a succession of European, Japanese, and American scholaradventurers, working primarily in Chinese Turkestan (present-day Xinjiang Uyghur Autonomous Region, which comprises China's vast northwest) and China's Gansu Province (to the immediate east of Xinjiang) rediscovered and often looted many of the ancient sites and artifacts of the Silk Road. The second era began to pick up momentum in the 1980 due to a number of geopolitical, cultural, and technological realities as well as the emergence of the New World History as a historiographical field and area of teaching. This second period of fascination with the Silk Road has resulted in not only a substantial body of both learned and popular publications as well as productions in other media but also in an ever-expanding sense among historians of the scope, reach, and significance of the Silk Road.
\end{abstract}

\section{Keywords}

Silk Road, Aurel Stein, Mogao Caves, Sogdians, Dunhuang Studies, Turfan, world history 


\section{THE SILK ROAD AS A HISTORIOGRAPHICAL CONSTRUCT}

Silk Road? Silk Roads? Silk Routes? Which is it and why? Today, most Anglophone scholars who write books and articles that are focused exclusively on these trans-Eurasian caravan routes that crisscrossed Eurasia's heartland in Late Antiquity and following prefer the evocative and admittedly misleading singular "Silk Road." Yet many (but certainly not all) world historians, whose historiographical vision impels them to view the past on a grand scale, choose to use the more correct plural form. ${ }^{1}$ Likewise, some contemporary world historians, who see the sea lanes of the Indian Ocean, the Red Sea, the Mediterranean, and similar avenues of maritime transportation as integral parts of the network of longdistance interchange in Late Antiquity and following, favor the term "Silk Routes," which lacks connotations of singularity and terrestriality. ${ }^{2}$ French historians almost universally favor the singular and romantic la route de soie (the Silk Route). ${ }^{3}$ German scholars likewise largely prefer the traditional and singular die Seidenstrasse (the Silk Road). ${ }^{4}$ It is significant, and tells us quite a bit about how old historical labels remain in vogue long after their accuracy has been questioned, that although historians now agree that silk was only one of many valuable items transported and traded along the Silk Road and also that, in the final analysis, the most historically important "commodities" carried along these routes were ideas and

${ }^{1}$ E.g., Jerry H. Bentley, Old World Encounters: Cross-cultural Contacts and Exchanges in Premodern Times (New York and Oxford: Oxford University Press, 1993), chapter 2, "The Era of the Ancient Silk Roads"; David Christian, "Silk Roads or Steppe Roads? The Silk Roads in World History," Journal of World History 11 (2000): 1-26; Felipe Fernández-Armesto, The World, a History (Upper Saddle River, New Jersey: Pearson Prentice Hall, 2007), 196-99, etc.

2 This is especially true of world historians who study pre-modern "world systems" of commercial exchange: Philippe Beaujard, "From Three Possible Iron-Age World Systems to a Single Afro-Eurasian World-System, Journal of World History 21 (2010): 1-43.

${ }^{3}$ E.g., Pierre Biarnès, La Route de la Soie: une histoire géopolitique (The Silk Road: A Geopolitical History) (Paris: Ellipses, 2008).

4 E.g., Hans-Joachim Klimkeit, Die Seidenstrasse: Handelsweg und Kulturbrücke zwischen Morgen- und Abendland (The Silk Road: Commercial Highway and Cultural Bridge between East and West) (Cologne: DuMont, 1988). But see Peter Suter, Die Seidenstrassen: Handelsverbindungen zwischen China und dem Westen von der Frühgeschichte bis zur Mongolzeit) (The Silk Roads: Commercial Conduits between China and the West from Antiquity to the Mongol Era) (Stäfa: Gut, 1987). 
culture and not goods, we still preface Road, Roads, or Routes with "Silk." But where, when, and why did the concept of a Silk Road or Silk Roads arise and become part of our historiographical vocabulary?

The father of both terms was the German geographer, geologist, and explorer Ferdinand von Richthofen, who coined the words Seidenstrasse (Silk Road) and Seidenstrassen (Silk Roads) in 1877.5 Richthofen used these neologisms sparingly and in quite limited ways. For him the Seidenstrasse was a single route to the "Land of Silk" as described by the first-century CE geographer Marinus of Tyre, which has come down to us in Ptolemy's second-century Geography, whereas the Seidenstrassen were the multiple trade routes between imperial Rome and Han China along which the precious commodity of silk traveled in substantial quantities from around $100 \mathrm{BCE}$ down to about $150 \mathrm{CE}^{6}$ As far as Richthofen was concerned, silk, which the Roman savant Pliny the Elder (23-79 CE) sourly noted cost the Roman Empire fifty million sesterces annually "so that a Roman matron might wear a transparent garment in public,"7 was the commodity above all others that drove this relatively short-lived era of trans-Eurasian commercial exchange. It was left to others to broaden and popularize the term. Chief among the second fathers of the Silk Road label were Albert Herrmann and, far more importantly, Richthofen's former student Sven Hedin (1865-1952), whose three, widely publicized archaeological and geographic expeditions in Xinjiang and Tibet between 1894 and 1908 went far in making "the Silk Road" part of the vocabulary of edu-

${ }^{5}$ Ferdinand Freiherr von Richthofen, China. Ergebnisse eigener Reisen und darauf gegründeter Studien (China: Results of a Personal Journey and Studies Based Upon It), 5 vols. (Berlin: Reimer, 1877-1912), vol. 1, passim; idem, "Über die zentralasiatischen Seidenstrassen bis zum 2. Jh. n. Chr." ("Regarding the Central Asian Silk Roads to the Second Century after Christ”), Verhandlungen der Gesellschaft für Erdkunde zu Berlin 4 (1877): 96-122.

${ }^{6}$ The best study of Richthofen's use of these terms is Daniel C. Waugh, "Richthofen's 'Silk Roads': Toward the Archaeology of a Concept," The Silk Road 5 (2007): 1-10; www.silkroad.com/toc/newsletter.html. Accessed January 18, 2013. See also Tamara Chin, "The Invention of the Silk Road, 1877," Critical Inquiry 40 (2013): 194-219. Chin seems not to know of Waugh's work, and her article suffers from a certain opaqueness of style and language.

${ }^{7}$ Ed. and trans. Alfred J. Andrea in Alfred J. Andrea and James H. Overfield, The Human Record: Sources of Global History, $7^{\text {th }}$ ed., 2 vols. (Boston: Wadsworth Cengage, 2012), 1:165. 


\section{cated Europeans and North Americans. ${ }^{8}$}

The widely-reported exploits of other adventurerarchaeologists in Chinese Turkestan (China's Xinjiang region), Gansu Province (to the immediate east of Xinjiang), and adjacent areas of Central Asia, who, in the period spanning the period from the 1890 s to the early 1930s, uncovered long-lost oasis cities and hidden caches of artifacts and documents, mapped vast regions of Central Asia, and carried back to museums in Europe, Japan, India, and the United States artistic treasures of every sort, 9 further popularized the Silk Road. Far more than that, their work created the field of Silk Road studies. ${ }^{10}$

THE FIRST PHASE: DisCOVERING AND “RECOVERING” THE TREASURES OF THE SILK ROAD

Without the discoveries and scholarly reports generated by these

${ }^{8}$ Albert Herrmann, Die alten Seidenstrassen zwischen China und Syrien (The Old Silk Roads between China and Syria) (Berlin: Weidmannsche, 1910). Among Hedin's voluminous writings on his expeditions and discoveries, see the English translation of his Sidenvägen. En bilfärd genom Centralasien (The Silk Road. A Drive through Central Asia) (Stockholm: Bonniers, 1936), trans. F. H. Lyon as The Silk Road (New York: E. P. Dutton, 1938). Waugh, "Archaeology," 6-7, provides details of their contributions to this popularization. Hedin's autobiographical My Life as an Explorer, illustrated by the author and translated by Alfhild Huebsch (Garden City, New York: Garden City Publishing Co, 1925), is filled with details that have excited the imaginations of generations of school boys and contributed substantially to creating the romance of the Silk Road.

9 Including murals ripped from cave walls. One of the most notorious but far from the most egregious acts of "preservation through removal" was Langdon Warner's unauthorized carrying off of a bodhisattva statue and mural fragments from Cave 328 at Dunhuang's Mogao Caves, Buddhist shrines that are described briefly below in the main text. An art historian at Harvard University, Warner deposited these purloined artifacts at the university's Fogg Museum in 1925. Today they reside in Harvard's Sackler Museum. Cave 328 is one of the handful of caves at Dunhuang that is permanently open to visitors, so that guides can lecture them on the effects of Western "imperialism." Warner's defense of his "labour of love" in removing these artifacts to keep "those crumbling pigments from harm" (144-45) can be found in his autobiographical The Long Old Road in China (Garden City, New York: Doubleday, Page \& Company, 1926).

${ }^{10}$ A well-written but far-from-complete survey of the exploits of the more notable (or notorious) of these adventurer-scholars is Peter Hopkirk, Foreign Devils on the Silk Road: The Search for the Lost Cities and Treasures of Chinese Central Asia (London: John Murray, 1980). Hopkirk's engaging book focuses on the adventures and occasional misadventures of six men: Sven Hardin of Sweden; Aurel Stein of Great Britain (by way of Hungary); Albert von Le Coq of Germany; Langdon Warner of the United States; and Count Otani of Japan, possibly a spy as well as an archaeologist. 
often rapacious pioneers, today's Silk Road scholarship would be almost unthinkable. Of all of these men, one stands out as a giant among giants: Sir Aurel Stein (1862-1943). ${ }^{11}$ Stein, who greatly enriched the holdings of London's British Museum (and later the British Library when the Silk Road scrolls he brought to England were transferred there) and India's National Museum in New Delhi, had an archaeological career along the Central Asian routes of the Silk Road that spanned the years 1900 to 1943 . Chief among these forays were four major expeditions in 1900, 1906-1908, 1913-1916, and 1930 into western China. The eminent archaeologist and contemporary Sir Leonard Woolley described Stein's four expeditions as "the most daring and adventurous raid upon the ancient world that any archeologist has attempted." ${ }^{12}$ That curiously ambiguous phrase, "raid upon the ancient world," whether intentionally equivocal or not, nicely encapsulates the double-edged nature of what Stein and all other pioneers of Silk Road archaeology were doing. A case in point is Stein's single greatest success (among so many notable discoveries), which brought him immediate fame and later, in the eyes of many latter-day anti-imperialists, infamy. In May 1907, Stein visited a complex of Buddhist cave-shrines on the edge of the Gobi Desert known as the Mogao Caves (Mogaoku, "Peerless Caves"), located about fifteen kilometers from the oasis town and early military outpost of Dunhuang in China's Gansu Province. For reasons of academic shorthand, the Mogao Caves are generally referred to simply as "Dunhuang" or "the Dunhuang Caves," even though they are located a significant distance from the town. ${ }^{13}$ In the first through tenth centuries $C E$, the era of the

${ }^{11}$ Actually, Marc Aurel Stein, but he favored not using Marc as a given name. Several excellent biographies of Stein are available in English: Jeannette Mirsky, Sir Aural Stein, Archaeological Explorer (Chicago and London: University of Chicago Press, 1977); Annabel Walker, Aurel Stein, Pioneer of the Silk Road (Seattle: University of Washington Press, 1995); Susan Whitfield, Aurel Stein on the Silk Road (Chicago: Serindia, 2004). All are illustrated, but Whitfield's book alone has color plates of some of Stein's finds.

${ }^{12}$ Quoted by Jeannette Mirsky in her introduction to a 1964 reprint of Aural Stein's 1933 memoir, On Ancient Central-Asian Tracks (Chicago and London: University of Chicago Press, 1964), xiii.

${ }^{13}$ Complicating matters is the fact that the small Yulin complex of Buddhist caves, which is located about one hundred kilometers east of Dunhuang, is often combined with the Mogao 


\section{Silk Road's greatest prosperity and utility, it was a commercially} and militarily strategic site ${ }^{14}$ located as it was at the eastern juncture of the two major Silk Road routes that skirted the southern and northern fringes of the massive Tarim Basin ${ }^{15}$ and its dreaded and essentially impassable Taklamakan Desert ("The Place from which No Living Thing Returns"). ${ }^{16}$ Often termed "the gateway to

Caves into a generic "Dunhuang Caves."

${ }^{14}$ In 111 BCE, Emperor Han Wudi established it as a military outpost. From those beginnings it became a commercial center and place of religious pilgrimage, hosting a variety of peoples.

15 About $906,500 \mathrm{~km}^{2}$.

${ }^{16}$ The Mogao Caves, which were declared a World Heritage Site in 1987, were dug out of the soft, composite-gravel stone of a cliff face. The caves number 735, of which 492 are decorated with murals and statuary, and extend a distance of about $1.6 \mathrm{~km}$. A few of the caves are simply small niches carved into the cliff face, whereas others are vast spaces that house massive statues and can accommodate hundreds of pilgrims. Cave 95, which rises nine stories, holds a thirty-five and a half meter-high Buddha - the third tallest in the world. Most caves fall between these extremes. According to legend, the first cave was dug out in $366 \mathrm{CE}$ by a solitary monk. If so, his cave is no longer identifiable. Most caves appear to have been excavated by professional engineers between the fifth and eleventh centuries and served a variety of purposes: places of worship and meditation; family mortuary shrines; places of pilgrimage; and sites that extolled the authority and piety of their patrons. Although the pace of excavation and decoration of the caves slowed considerably after about 1100 , work on creating new caves and beautifying existing ones extended at least into the late fourteenth century. The caves cumulatively contain about three thousand statues and murals, all apparently created by professional artists. Were all this art laid end to end, it would measure about twenty- six kilometers in length by four and a half meters in height.

There are many illustrated books on the art of these caves. The most authoritative is Roderick Whitfield, with photographs by Seigo Otsuka, Dunhuang: Caves of the Singing Sands: Buddhist Art from the Silk Road, 2 vols. (London: Textile and Art Publications, 1995). See also Roderick Whitfield, Susan Whitfield, and Neville Agnew, Cave Temples of Dunhuang: Art and History on the Silk Road (Los Angeles: Getty Conservation Institute and the J. Getty Museum, 2000); Fan Jinshi, The Caves of Dunhuang (Hong Kong: Dunhuang Academy, 2010); Zhang Wenbin et al., Dunhuang: A Centennial Commemoration of the Discovery of the Cave Library (Beijing: Morning Glory Publishers, 2000).

An excellent narrative description of the Library Cave and its contents is Valerie Hansen, Chapter 6, "The Time Capsule of Silk Road History: The Dunhuang Caves," The Silk Road: A New History (Oxford and New York: Oxford University Press, 2012), 167-98. This is a book that every student of the Silk Road should own.

Dunhuang is only one of many Buddhist cave complexes along the Silk Road. Others of almost equal importance are the complexes at Bezeklik, northeast of the Taklamakan Desert, and Kizil in western Xinjiang. In 1906, the German explorer Albert von Le Coq removed many of the most important of Bezeklik and Kizil's murals, which he then deposited in Berlin. A significant number of them were destroyed in the bombings of World War II; the survivors are today in Berlin's Museum of Asian Art. Fragments of the murals also made their way to Japan, Korea, Russia, and the United States. Valerie Hansen, Silk Road, 61-65, describes the Kizil Caves and Le Coq's technique for removing the murals. 
the Silk Road," it was the major crossroad of all long-distance, eastwest traffic.

Although specific caravan routes opened, closed, and shifted from time to time due to changing environmental and political realities, ${ }^{17}$ the northern and southern bypasses around the forbidding Tarim Basin were a constant fact of Silk Road travel. For merchants, pilgrims, missionaries, soldiers, diplomats, and others either setting out from China's heartland or returning to it, the Buddhist cave complex and its attendant monasteries outside Dunhuang were places of rest, and for those who accepted the Law of the Buddha, the cave-shrines were a source of spiritual comfort as they either prayed for a safe outward journey or offered prayers of thanksgiving for their safe return.

Apart from its undoubted importance to Silk Road travelers, what most attracted Stein to this site was that he had heard that a Daoist monk, Wang Yuanlu, had, seven years earlier, discovered more than 40,000 manuscripts and printed documents in a wide variety of Silk Road languages as well as large numbers of painted silken banners that had been walled up in a small cave for anywhere from seven to nine hundred years, where they had been largely preserved from the ravages of heat, moisture, disease, and insects. ${ }^{18}$ After much negotiation, Stein convinced Wang to accept a contribution toward the preservation of the Mogao cave-shrines and construction of a guesthouse for pilgrims ${ }^{19}$ in exchange for sev-

${ }^{17}$ Loulan, an important garrison town, whose ruins Stein excavated in 1906 and 1914, flourished only from the second century BCE to the early fourth century CE, when it was abandoned due to drought. Nearby Miran, at which, in January 1907, Stein found Buddhist frescoes that displayed definite Roman stylistic influences, was abandoned in the ninth century when the Tibetan Empire pulled out of the region.

18 The date of and reason for their entombment has been the subject of a good deal of learned discussion. A typical foray into this probably insolvable issue is John C. Huntington, "A Note on Dunhuang Cave 17, 'The Library,' or Hong Bian's Reliquary Chamber," Ars Orientalis 16 (1986): 93-101. See also Rong Xinjiang, "The Nature of the Dunhuang Library Cave and the Reasons for Its Sealing," trans. Valerie Hansen, Cahiers d'Extreme-Asie 11 (1999-2000): 247-75.

${ }^{19}$ The treasures were housed in Cave 17, the so-called Library Cave. Standing across from the cave is a modestly sized exhibition hall that was renovated in 2000 and is devoted to telling the story of the manner in which the treasures of the Mogao Caves were stolen by foreigners. Ironically it is the restored guesthouse that originally had been built by Wang out of the silver ingots given him by Stein for these treasures. 
eral cartloads of these antiquities. Stein was able to give the documents a cursory inspection, but he quickly perceived that the multiplicity of languages that they represented was proof positive of Dunhuang's rich multi-culture environment in the age of the Silk Road. ${ }^{20}$ Among the treasures that Stein carted away was a blockprinted scroll of the Diamond Sutra dating to 868-the world's oldest-known, intact printed book. ${ }^{21}$ The spoils of Dunhuang, were subsequently divided between Stein's patrons in England ${ }^{22}$ and India, and ultimately deposited in museums where they were avidly studied. Study and cataloging of the treasures that he brought to England was largely carried out by a team of scholars working at the British Museum because Stein, who was fluent in at least eight languages, including Sanskrit and Old Persian, lacked sufficient knowledge of Chinese, the language in which most of the Buddhist texts were written, ${ }^{23}$ and the temperament to confine himself to a museum basement.

Within a few years of his return to England, Stein composed an account of this second expedition for a general audience, ${ }^{24}$ but it was not until 1921 that he finally published a multi-volume report

${ }^{20}$ In addition to Chinese, the languages included Tibetan, Sanskrit, Runic Turkish, Khotenese, Kuchean, and a language totally unknown to Stein that turned out to be Sogdian, the Iranian tongue of a people from western Central Asia. See note 36 regarding the Sogdians. Although there were a few secular documents, most of the texts were Buddhist. Additionally there were texts relating to the Christianity of the Church of the East (today known as the Assyrian Church of the East and often misnamed the Nestorian Church), Judaism, Zoroastrianism, and Manichaeism - evidence of the rich cosmopolitanism of Dunhuang. Manichaeism, "the Religion of Light," was a syncretic world religion from Iraq that had made deep inroads into Central Asia on both sides of the Pamirs. Hans Joachim Klimkeit, Gnosis on the Silk Road: Gnostic Texts from Central Asia (San Francisco: HarperSanFrancisco, 1993), has translated a wide variety of Manichean texts from the Silk Road, texts that were largely uncovered by the German archaeologists Albert Grünwedel and Albert von Le Coq along the northern fringe of the Taklamakan Desert between 1902 and 1914 at Turfan. The texts of Turfan are briefly described below.

${ }^{21}$ Frances Wood and Mark Barnard, The Diamond Sutra: The Story of the World's Earliest Dated Printed Book (London: British Library, 2010).

${ }^{22}$ Stein deposited at the British Museum twenty-four cases of documents and five cases of painted banners, textiles, and varied "art relics," including archaeological and artistic treasures from Loulan and Miran (note 17); Stein, Central-Asian Tracks, 184.

${ }^{23}$ Stein estimated that the Chinese Buddhist documents alone brought away from Dunhuang in 1907 and deposited at the British Museum comprised more than 3,000 complete scrolls, close to 6,000 other Buddhist works, including detached pieces of text, and numerous fragments of secular works of Chinese scholarship; Ibid., 186-87.

${ }^{24}$ Aurel Stein, Ruins of Desert Cathay (London: Macmillan and Co, 1912). 
of his Second Expedition and the antiquities brought back from Dunhuang and elsewhere. In the strange title of that work, he gave the world a new term, "Serindia," as a way of describing that vast area of cultural interchange along the Silk Road that stretched from the Pamir Mountains at the western edge of Chinese Turkestan to Dunhuang. ${ }^{25}$ This neologism derives from the Latin word Seres ("the people of silk"), the term the ancient Romans used for the mysterious people of the East who produced silk, and "India," the home of many cultural elements, such as Buddhism, that traveled along the Silk Road.

Other adventurer-scholars followed Stein in visiting and carrying away precious items from the treasure trove that Wang Yuanlu had discovered. Most notable of these second-round collectors was the eminent French orientalist Paul Pelliott (1878-1945), whose expertise in Chinese and various Central Asian languages allowed him to study the large number of documents that Stein had not been able to carry away. He chose his documents wisely. After paying Wang the equivalent of £9o, Pelliott was able to bring back to Paris in 1909 a vast collection of scrolls and art objects. The documents were transported to the Bibliothèque nationale de France, whereas the works of art were ultimately deposited in the Guimet Museum, where they became known as the Pelliott Collection. ${ }^{26}$

${ }^{25}$ Aurel Stein, Serindia, 5 vols. (Oxford: Clarendon Press, 1921). A descriptive catalog of the art that Stein deposited in both Great Britain and India was composed by Arthur Waley, $A$ Catalogue of Paintings Recovered from Tun-huang by Sir Aurel Stein (London: British Museum, 1931). The definitive catalog of the art taken from Dunhuang and brought to the British Museum is the first two volumes of Roderick Whitfield, The Art of Central Asia: The Stein Collection in the British Museum, 3 vols. (Tokyo: Kodansha International, 1982-1985). The catalog by Roderick Whitfield and Anne Farrer, Caves of the Thousand Buddhas: Chinese art from the Silk Route (New York: George Braziller, Inc., 1990), commemorates the exhibition of treasures from the Stein Collection that inaugurated the newly refurbished gallery of the British Museum's Department of Oriental Antiquities. In addition to highlighting paintings and textiles taken from the Mogao Caves, it also shows in vivid color a wide variety of archaeological treasures from all of Stein's Central Asian expeditions. Lokesh Chandra and Nirmala Sharma, Buddhist Paintings of Tun-huang in the National Museum, New Delhi (New Delhi: Niyogi Books, 2012), offers a rich display of treasures from its Stein Collection.

${ }^{26}$ Jacques Giès, ed., Les arts de l'Asie centrale: la collection Paul Pelliot du Musée nationale des arts asiatiques (The Arts of Central Asia: The Paul Pelliot Collection of the National Museum of Asian Arts), 2 vols. (Paris: Réunion des musées nationaux, 1995-1996). (Text only translated by Hero Friesen in collaboration with Roderick Whitfield as: The Arts of Central Asia: the Pelliot Collection in the Musée Guime. [London: Serindia, 1996]) 
Other European collectors of some of Cave 17's treasures brought their purloined goods to the Berlin Library and the Oriental Institute in St Petersburg. Additionally, Chinese officials finally tried to put a stop to the pillaging of Cave 17's treasures and ordered that all remaining items be transferred to the capital. Despite Wang's slyly keeping back a considerable number of manuscripts, which he subsequently allowed Stein to carry away in $1914,{ }^{27}$ and inevitable pillaging along the way, a large trove reached the capital in $1910 .{ }^{28}$ Today the bulk of the manuscript remnants of the Library Cave are stored at the National Library of China in Beijing, with other libraries and learned institutions throughout China holding far smaller collections of Dunhuang's treasures.

With this wealth of Silk Road art and records scattered about in museums and libraries in Europe, Asia, and America, scholars had plenty to command their attention. But then came the Second World War and the subsequent closing down of Central Asia and China for a generation and more so far as most Western scholars were concerned, but as we shall see, this did not end all interest in or research and writing on the Silk Road in the period between the mid-1930s and the 1980s.

\section{THE SECOND PHASE: INSTITUTIONALIZING THE SILK ROAD}

In the heat and oppressive humidity of late June and early July, 2002, approximately 1.3 million visitors attended the thirty-sixth annual Smithsonian Folklife Festival on the National Mall in Washington, D.C., and more than 350,000 of them purchased the extensive program, which contained short but informative essays on a number of Silk Road phenomena. ${ }^{29}$ What made this festival unique in the history of such events is that it centered not on the folk ways

${ }^{27}$ On Stein's Third Expedition, Stein, Central Asian Tracks, 185.

${ }^{28} 8,697$ manuscripts; subsequent donations and purchases brought its Dunhuang holdings to about 16,000 .

${ }^{29}$ An on-line copy of the program is available at http://www.festival.si.edu/past_festivals /silk_road/program.aspx. Accessed January 22, 2014. 
of two or three discrete cultures, but rather its theme was the lands and peoples of the Silk Road throughout history, and it highlighted both the traditional and contemporary modes of expression of peoples from Japan to Italy who had been part of the Silk Road story for over 2,00o years. Titled "The Silk Road: Connecting Cultures, Creating Trust," it was the Smithsonian's answer to the attacks of 9/11..$^{30}$ This celebration of two millennia of cultural exchange featured, among its thousands of artistic performers, the cellist Yo-Yo Ma and the Silk Road Ensemble. In the spirit of the musical interchanges that had occurred along the historic Silk Road, in which a variety of instruments, ${ }^{31}$ harmonic motifs, and modes of dance, such as the Sogdian swirl, traveled from Central Asia and India to East Asia, where they were taken up and transformed by their host cultures, Yo-Yo Ma put together in 1998 the Silk Road Ensemble, which brings together musicians from throughout Asia as well as the West and blends instruments and musical styles in new ways. ${ }^{32}$ Anyone attending these concerts and other performances or walking the Mall and visiting the numerous exhibitions of ancient and modern crafts, would have to say, "The Silk Road has fully arrived."

And it is true. In the wake of the intensification of Silk Road studies, especially over the past three decades, the Silk Road has become a popular cultural phenomenon. In 2008, "The Lights of Dunhuang," an exhibition of Buddhist art from northwest China that was held at Beijing's National Art Museum of China, drew record crowds, despite limits placed on daily attendance for reasons of safety. In the compass of only two months, approximately 660,00o

${ }^{30}$ Mark Slobin, "The Silk Road Wends its Way to Washington," Middle Eastern Studies Association Bulletin 36 (2003): 194-99, provides a brief overview, but the Smithsonian Folklife Festival website (note 29) is far more informative and provides photos.

${ }^{31}$ The Chinese pipa, a pear-shaped lute, probably arrived from what is today Pakistan during the era of the Han dynasty (202 BCE-220 CE). It later served as the model for the Japanese biwa. James A. Millward, "The Pipa: How a barbarian lute became a national symbol," June 10, 2011 in Danwei: Tracking Chinese Media and Internet at http://www.danwei.com/thepipa-how-a-barbarian-lute-became-a-national-symbol/. Accessed January 25, 2014.

${ }^{32}$ The Silk Road: A Musical Caravan. A compilation of various artists. 2 CD set, 47 tracks, 146 minutes. Produced by Smithsonian Folkways Recordings in partnership with the Silk Road Project Inc., SFW CD40438, 2002. 
visitors, mainly Chinese, crowded in to view the artifacts. 33 Further, one cannot pick up a travel magazine in any Western language without seeing advertisements for escorted Silk Road tours to places that were largely closed to travelers from outside only a generation ago. Walking down a back street in Bukhara, one finds the Silk Road Spices shop. Hardly a major city in the West, or anywhere else for that matter, does not have at least one Silk Road restaurant. But before that happened, beginning in the 1980s, the scholarly world was well on its way toward intensifying Silk Road studies to the point of institutionalization.

This is not to say that the Silk Road had become totally moribund as a topic of interest from the mid-1930s to about 1980. Chinese artists, art historians, historians, and others continued to be interested in the glories of their remote past even as they were assailed by the vicissitudes of contemporary life: the breakdown of central authority after 1911, invasion and war, and, perhaps most threatening of all, a Cultural Revolution that denied the legitimacy of the past. In 1944, in the midst of World War II and with growing discord between Communists and Nationalists becoming a prelude to all-out civil war, a weak central government instituted the Dunhuang Art Institute staffed by artists commissioned to copy Dunhuang's cave murals as a patriotic act. In 1950, even amid all of the domestic and international problems faced by the new PRC (including a looming war in Korea), the Dunhuang Art Institute was reconstituted as the Dunhuang Research Institute of Cultural Properties, but it conducted precious little research and focused instead on continuing the work of copying cave art. Yet, the process was underway that would lead to the creation of a first-class academy at Dunhuang dedicated to the conservation and study of the caves when, toward the end of the 1970s, Duan Wenjie, an artist turned art historian took over as director. 34 We shall see the

${ }^{33}$ National Art Museum of China (NAMOC), site: http://old.namoc.org/en/about_Namoc /History.index.hml. Accessed January 23, 2014.

${ }^{34}$ Researched by Professor Ning Qiang, Chu-Niblack Associate Professor in Asian Art and Curator of the Chu-Griffis Asian Art Collection, Connecticut College for the Silkroad Foundation website: http://www.silk-road.com/dunhuang/dhprogram.html. Accessed January 24, 2014. 
Dunhuang Academy below. Likewise, in the West, a handful of Silk Road scholars, largely specialists on China and eastern Central Asia, such as Owen Lattimore (1900-1989), continued to keep the beacon fires burning, no matter how dimly. 35 Then came the turn-around.

A number of phenomena beginning around the early 1980 os and following contributed to this upsurge in interest in the Silk Road and the consequent, so-called second phase of Silk Road studies. Chief among them were two geopolitical realities: the opening up to the world of the People's Republic of China (PRC), which began in 1979 under Deng Xiaoping and has continued with increasing momentum for three and a half decades; and the dissolution of the Soviet Union in 1991, which brought with it the subsequent emergence of independent and fairly open Central Asian states, such as Uzbekistan, whose lands had been home to peoples and polities that had played important roles along the Silk Road. ${ }^{6}$ Other contributing factors, in a rough order of priority, were: 1) the ever-growing divorce between political ideology and scholarship at the PRC's academic institutions following the death of Mao Zedong in 1976 and the ending of the Cultural Revolution; 2) the concomitant drive toward excellence of the PRC's universities and other learned institutions, especially those dedicated to archaeology and history, which, among other consequences, resulted in intensive archaeological excavations at Silk Road sites and publication of numerous Silk Road sources; 3) the proliferation throughout China

${ }^{35}$ Among Lattimore's many works, see Studies in Frontier History: Collected Papers, 1928-1958 (London and New York: Oxford University Press, 1962).

36 The most important were an Iranian people known as the Sogdians, who resided in city-states located what are today Uzbekistan and Tajikistan and who, between roughly 500 and 1000 CE played significant roles as merchants and transmitters of culture in trade diasporas that were scattered along the routes of the Silk Road. Valerie Hansen's review essay on the Sogdians is invaluable: "New Work on the Sogdians, the Most Important Traders on the Silk Road, A. D. 500-1000," T'oung Pao, Second Series, 89 (2003): 149-61. Far more accessible to the average reader and a joy to read is her "Homeland of the Sogdians, the Silk Road Traders: Samarkand and Sogdiana," Silk Road, 113-39. See also Jonathan Karam Skaff, "The Sogdian Trade Diaspora in East Turkestan during the Seventh and Eighth Centuries," Journal of the Economic and Social History of the Orient 46 (2003): 475-524; and Étienne de la Vaissière, Histoire des marchands sogdiens [History of the Sogdian Merchants] (Paris: Collège de France, 2002, revised 2004). A translation of the revised edition by James Ward appears as Sogdian Traders: A History (Leiden: Brill, 2005). 
and beyond of institutions devoted to Silk Road studies; 4) the emergence of world history as a historiographical movement that focuses on a study of a past that transcends single cultures, regions, and polities and emphasizes historically significant contacts and exchanges among peoples - the very stuff of Silk Road studies;37 5) creation of a world-wide web on the internet; and 6) a growing affluence, not only among Westerners and citizens of such prosperous East Asian nations as the Republic of Korea, Japan, and Singapore, but also in China, which has led to a great upsurge in tourism along the exotic sites of the Silk Road.

The earliest institutionalization of the Silk Road on a grand scale was inaugurated by UNESCO in 1988. Taking an ecumenical view of the Silk Roads (UNESCO's favored term) that was in tune with the vision of the new world historians and that went far beyond the traditional concentration on eastern Central Asia that characterized so much of the first phase of Silk Road studies that had been led by Stein and other "foreign devils," UNESCO created a ten-year multidisciplinary project that it titled "Integral Study of the Silk Roads: Roads of Dialogue," a program dedicated to furthering Silk Road research and disseminating information relating to the Silk Road to scholars, educators, students, and the general public alike. In doing so, it declared that:

The term 'Silk Roads' refers to a vast network of land and maritime trade and communication routes connecting the Far East, Central Asia, the Indian sub-continent, Iranian and Anatolian plateaus, the Caucasus, the Arabian peninsula and the Mediterranean region and Europe. The incessant movement of peoples and goods along these routes resulted in an unprecedented transmission and exchange of knowledge, ideas, beliefs, customs and traditions over three millennia..$^{8}$

More out of a sense of hope and an ideology that springs from UNESCO's overall mission rather than reflecting a solid grounding in historical scholarship, the home page of this project further de-

${ }^{37}$ A hallmark of this movement was the establishment of the World History Association in 1982. The website of the WHA is http://www.thewha.org.

${ }^{38}$ Home page of the UNESCO Silk Roads Project website: http://www.unesco.org /new/en/culture/themes/dialogue/routes-of-dialogue/silk-road/. Accessed January 25, 2014. 
clares:

These peaceful exchanges between East and West, which have profoundly shaped and enriched the cultures along the Silk Roads, hold many valuable lessons for contemporary societies about the potential of intercultural dialogue. ${ }^{39}$

Well, there were many peaceful exchanges along the Silk Roads, but wars and conflicts were equally part of the long saga. ${ }^{40}$

Naïveté aside, its achievements were impressive over that decade. It funded five major academic expeditions between 1990 and 1995, sponsored twenty-six international seminars, underwrote numerous research projects (including Klimkeit's translation of Manichaean texts that is listed above at note 20) and publications, established research centers, granted research fellowships, funded conservation projects (such as conserving Central Asian caravanserais), and created audio-visual materials for educators and a general audience. ${ }^{41}$ Today its good work continues with "The Silk Road: Dialogue, Diversity, and Development," an on-line platform aimed largely at a general audience. ${ }^{42}$

An equally impressive and far-reaching institution created to further Silk Road studies and to make such scholarship available to a global audience is the International Dunhuang Project (IDP). Formed in 1994, the IDP has taken on the mission "to make information and images of all manuscripts, paintings, textiles and artefacts from Dunhuang and archaeological sites of the Eastern Silk

${ }^{39}$ Ibid.

${ }^{40}$ Susan Whitfield, director of the International Dunhuang Project that is described below, has written an engaging book for students and the general public in which, through the experiences of five fictional and five semi-fictional persons, she presents a panorama of the varieties of life along the eastern Silk Road in the period 750-1000: Life along the Silk Road (Berkeley and Los Angeles: University of California Press, 1999). Each of these largely fictionalized biographical sketches is based on documents from Dunhuang and has, therefore, verisimilitude. As several of the stories, especially "The Horseman's Tale," 76-94, make clear, conflict was a constant reality along the Silk Road.

${ }^{41}$ Enumerated and described in the 2008 report The Silk Roads Project: "Integral Study of the Silk Roads: Roads of Dialogue,” 1988-1997 at http://unesdoc.unesco.org/images/0015/001 591/159189E.pdf. Accessed January 25, 2014.

${ }^{42}$ Home page at: https://en.unesco.org/silkroad/. Accessed January 25, 2014. 
Road freely available on the Internet and to encourage their use through educational and research programmes." 43 As of January 23, 2014, it had placed 418,039 images on its interactive website. ${ }^{44}$ One day earlier it boasted 417,468 images, 45 which gives us a good idea as to the pace of its work and its commitment to this project. Additionally, its website contains essays on aspects of the Silk Road, and it has a newsletter with additional articles of interest to scholars and the general public alike. Issue 38 (winter 2011-2012), for example, is devoted to essays on the history, transmission, and spiritual significance of the Diamond Sutra and details on the Library's conservation of the printed scroll that Stein recovered in $1907.4^{46}$ The IDP's directorate is located at London's British Library, to which almost all of the Silk Road documents brought to England by Aurel Stein and initially housed at the British Museum were transferred by 1982,47 but, unlike the time of Aurel Stein, it has put aside all notions of British exclusivity. Seven international partner institutions in Asia and Europe provide data, serve as hosts for the IDP's multilingual data base and website, and are centers for the training of staff in the use of digital media and conservation techniques. Significantly two of those seven, which combine to produce a Chinese-language website, are in the People's Republic of China-the National Library of China in Beijing and the Dunhuang Academy at the Mogao Caves. Despite official China's bitterness at the rapacity of archaeologists such as Stein and its on-again-off-again efforts to repatriate these treasures, its scholars are committed to this British-led project. The IDP's other major partners are located in Korea, Japan, Russia, Germany, and France and serve websites in each of ${ }^{43}$ Quoted from the IDP's home page: http://idp.bl.uk/. Accessed January 24, 2014
${ }_{44}$ Ibid., accessed January 24, 2014.
${ }^{45}$ Ibid., accessed January 23, 2014.
46 IDP site: http://idp.bl.uk/archives/news38/idpnews_38.a4d\#7. Accessed January 24,
2014. Regarding this block-printed sutra, see above, note 21.
47 The British Museum continues to hold the Stein Collection paintings, sculptures, coins, and sundry other artifacts, whereas the Victoria and Albert Museum houses Silk Road textiles. Other depositories in the United Kingdom hold smaller collections. Helen Wang, ed., Handbook to the Stein Collections in the U.K. (London: British Museum, 1999), is a handy guide to all of these Stein Collections. 
these national languages. ${ }^{8}$ Additionally, fifteen other IDP partners, such as the Musée Guimet in Paris and the Sven Hedin Foundation in Stockholm, provide data from their collections. The Academia Sinica in Taipei, Taiwan is one of the fifteen, demonstrating that international academic cooperation can, at least in some cases, transcend political division.

The IDP also conducts educational outreach programs, including sponsoring public lectures and exhibitions on aspects of the Silk Road in Chinese Turkestan. As these words are being written, it is co-sponsoring the exhibition "Aurel Stein and the Silk Road: a hundred years on" at the Royal Geographical Society, London (January 6-February 14, 2014).49

Unlike UNESCO's Silk Roads projects, the IDP focuses on what we might call the traditional center of interest of Silk Road studies, the eastern routes that led from Chang'an (present-day Xi'an) to Kashgar, where the northern and southern routes skirting the Tarim Basin met. And that is quite understandable, considering the materials from early twentieth-century explorers that it is working with-materials that came from that region of western China. Indeed, the IDP's work supports a new trend in Silk Road studies that some have termed "Dunhuangology," but most prefer to call "Dunhuang Studies."

Dunhuang Studies have a starting point: analysis of the documents and artifacts recovered from the Library Cave and the mural and sculptural art of the other 491 Mogao Caves. But that is only a starting point-a critical center. Like the ripples caused by a rock thrown into water, Dunhuang Studies moves out in ever widening concentric circles to encompass studies based upon the documents, artifacts, and art of similar sites and caches throughout China, especially its western regions. Not a discipline unto itself or even a distinctive historiographical field, Dunhuang Studies is a multi-

${ }^{48}$ Research Institute of Korean Studies, Seoul, Korea; Ryukoku University, Kyoto, Japan; The Institute for Oriental Manuscripts, St. Petersburg; The Berlin-Brandenburg Academy of Science and Humanities, Berlin, Germany; and Bibliothèque nationale de France, Paris, France.

49 IDP website: http://idpuk.blogspot.co.uk/2014/01/exhibition-opens-today-aurel-steinand.html. Accessed January 24, 2014. 
disciplinary focus on and analysis of a vast treasure trove of Silk Road materials from Dunhuang and far beyond Dunhuang, especially materials dating before the thirteenth century and the Mongol conquest of China. $5^{\circ}$ Such evidence, for example, includes the Turfan documents.

The Turfan Depression, located about 550 kilometers from Dunhuang along the northern route that skirted the Tarim Basin, is the second lowest and one of the hottest places on earth, but it is also a large oasis, measuring 170 square kilometers of fertile soil. Because of its water, it was a center of intensive agriculture as well as commercial and cultural interchange between Sogdians ${ }^{51}$ and Chinese, especially during the first century and a half of the reign of China's Tang dynasty (618-907), a period of heightened Silk Road activity. Turfan was noted for its superior melons, grapes, and wine production, fruits and a process introduced from the Sogdians' homeland in western Central Asia. ${ }^{52}$

Beginning in 1893 and extending into the 1930s, a series of Russian, German, and Japanese expeditions explored and exploited the Turfan area, carrying away large amounts of manuscripts written in Chinese and a wide variety of known and unknown Central Asian languages, many of them reflecting the range of religions at Turfan. As always, they also carried away art works and numerous other artifacts. Even Aurel Stein came and left with some manuscripts and other treasures. But some of the best was still to be discovered.

Thirty-seven kilometers beyond the city of Turfan but well within the Turfan Depression was the ancient city of Gaochang,

${ }^{50}$ Regarding Dunhuang Studies, see Rong Xinjiang, Eighteen Lectures on Dunhuang, trans. Imre Galambos (Leiden: Brill, 2013). See especially "What is 'Dunhuang Studies'?" 1-3. The title and format of this important book is a clever homage to a famous eighth-century Silk Road poem Eighteen Songs of a Nomad Flute, which tells the story of Lady Wenji, who was carried into captivity by the Xiongnu in the last decade of the second century CE.

51 Note 36.

52 There is no definitive or even tentative list of the cultural exchanges that traveled in every direction along the Silk Road for the 1500 years or so of its efflorescence, but Edward $\mathrm{H}$. Schafer has produced The Golden Peaches of Samarkand: A Study of T'ang Exotics (Berkeley and Los Angeles: University of California Press, 1963), which lists and describes exotica introduced into Tang China (618-907). 
now just standing ruins, and just outside its walls is the Astana Cemetery, which Stein had explored and from which he removed artifacts. But the sheer magnitude of the burial ground and the press of time prevented his exploring more than a small fraction of the graves. The cemetery contains about 3,000 tombs, largely of Chinese, and even today most tombs remain unexcavated. Between 1958 and 1975, Chinese archaeologists hurriedly dug up, and not always according to the best archaeological protocols, a number of tombs. Regardless of the sloppiness of their techniques, in 205 of them they found paper fragments containing texts in a variety of languages that had been fashioned into burial belts, shoes, and hats. Additionally, bodies were propped up by bundles of paper. Piecing these fragments together to form coherent texts is a labor equal to that of working on the Dead Sea Scrolls, 53 and it is as historically significant. It shows us the Silk Road at its grassroots at a time of particular importance to Silk Road interchange. The recovered documents number about two thousand, of which more than three hundred are contracts, and date from 273 CE to 769.54 These, as well as other fiscal documents, most significantly tax records, and a substantial number of unearthed silver coins, most of them either of Sassanian Persian or Islamic origin, give us a good idea of Turfan's long-distance commercial networks. As Valerie Hansen has put it, "these [tax] records highlight the dominant role played by Sogdians in the Silk Road trade." 55

Dunhuang Studies also flourish today at the Dunhuang Academy, a multi-disciplinary learned institution that has its headquarters at the Mogao Caves and is interested exclusively on the Buddhist caves of Dunhuang and the cultural influences that flowed through this region. Yet in doing so, it is a major force in furthering Silk Road research. As we have already seen, it is a major partner of

${ }^{53}$ An appropriate analogy also because the Dead Sea is the lowest point on earth, and its heat, as is the case at Turfan, preserved the documents from decay.

${ }^{54}$ Valerie Hansen, "Midway between China and Iran: Turfan," in The Silk Road, 83-112; idem, "Introduction: Turfan as a Silk Road Community," Asia Major, $3^{\text {rd }}$ Series, 11 (1998): 1-11. Zhang Guangda and Rong Xinjiang, "A Concise History of the Turfan Oasis and Its Exploration," Asia Major, $3^{\text {rd }}$ Series, 11 (1998): 13-36.

${ }^{55}$ Hansen, Silk Road, 99. 
the IDP. Its main mission, however, is protecting the actual caves, which were opened to visitors in 1980 and are now suffering from an over-abundance of touristic interest.

Non-stop flights from Beijing, Xi'an, Lanzhou, and Chengdu annually bring in hundreds of thousands of tourists-ninety percent of whom are Chinese on group guided tours. In 2006, the total number of visitors topped a half million. As a result, the humidity from human bodies (in an otherwise dry climate) is threatening the art, causing some murals to pull away from their surfaces. The Academy has countered this in several ways. Since 1989, it has worked closely with the Getty Conservation Institute (GCI) of Los Angeles, California. ${ }^{6}$ The first step was to create an overall site plan to protect the complex from human and environmental threats. Based on that plan, the GCI funded the construction of a barrier on the dunes above the cliff face to reduce the invasion of sand, which in the past has buried some caves. Then, since 1995, the GCI's technicians have been at work conserving those wall and ceiling paintings that have most badly deteriorated and shoring up a few caves that are in imminent danger of collapsing. The Academy also carefully monitors public access to the caves, making only a few of the caves available to the general public and then mandating a number of strict protocols - such as the need to be accompanied by the Academy's trained guides and an absolute prohibition of all cameras and mobile phones at the caves. Scholars may apply for permission to visit specific caves that are not open to the public, but in order to secure a guide with keys for the multi-locked steel door that secures the desired cave, one must pay a high fee, sometimes several hundred dollars for a single cave. Dunhuang Studies do not come cheaply. The Academy already has built an exhibition center across from the caves with a museum exhibiting artifacts unearthed at Dunhuang and replicas of ten of the most popular caves. Two of the replicas, of the sixth-century Cave 432 and the eighth-century Cave 45, were transported recently to New York City, where they served as the focal points for the China Institute's 
exhibition "Dunhuang: Buddhist Art at the Gateway of the Silk Road" (April 19-October 6, 2013).57 This exhibition center at the caves, as interesting and sophisticated as it is, is only a stop-gap measure. With the support of the government of the PRC and the assistance of Friends of Dunhuang, a non-profit organization founded in the United States in 2007, the Academy has begun construction of a new state-of-the art visitors' center fifteen kilometers away in Dunhuang, where everyone will receive a digitized tour of the caves in a 360-degree domed hall, meet a guide, and then be bused to the caves for an even more carefully controlled visit of a few caves. The visitors will also visit the refurbished exhibition center for a multi-media presentation, and then bused away. Thanks to a grant from the Mellon Foundation, already twenty-two cave interiors have been digitized, with many more to follow. When fully available on-line, the digitized images of all 492 caves will be of immeasurable value to art historians around the world..$^{8}$

In addition to this work of conservation and preservation, the Dunhuang Academy publishes an academic journal, Dunhuang Yanjiu (Dunhuang Researches), maintains a library for visiting researchers, and sponsors seminars on Dunhuang Studies broadly defined. In 2004 and 2008, it conducted multi-day seminars in Chinese and English with groups of academics, largely from the United States, who had arrived for several weeks of study at the caves led by Roderick Whitfield, the world's leading authority on the art of Dunhuang. This, and the extended tour of other Silk Road sites that followed the Dunhuang experience, was sponsored by the Silkroad Foundation of Saratoga, California.

The Silkroad Foundation, under the direction of its founder and executive director, Adela Lee, and with the cooperation of such U.S. universities as Stanford, Yale, and Princeton, has been furthering Silk Road studies in the United States and China since the

57 Home page of the China Institute's exhibition at: http://www.chinainstitute.org /dunhuang-2013-virtual-tour/. Accessed January 25, 2014.

${ }^{58}$ Friends of Dunhuang website at http://www.friendsofdunhuang.org/visitor-center.php center.php?lang=en. Accessed January 25, 2014. Further information and a free newsletter is available by registering at info@ friendsofdunhuang.org. 
1990s. It describes itself as a privately funded non-profit organization established to promote the study and preservation of cultures and art in Inner Asia and on the Silk Road.59 In addition to sponsoring seminars and scholarly expeditions and archaeological surveys along the Silk Road in the People's Republic of China, it maintains Silk Road House in Berkeley, California, a cultural and educational center that coordinates lectures and other Silk Road activities in the San Francisco-Berkeley Bay and Palo Alto areas. ${ }^{60}$ Working with Silk Road Seattle at the University of Washington in Seattle, Washington, the foundation also underwrites the on-line journal The Silk Road. ${ }^{61}$ Silk Road Seattle, under the direction of Daniel C. Waugh, professor emeritus of history at the university and also editor of The Silk Road, describes itself as devoted to exploring cultural interactions across Eurasia from the beginning of the Common Era to the seventeenth century and furthering learning and teaching along those lines. With this mission in mind, Silk Road Seattle's website provides on-line translations of key historical texts, teaching and learning guides, maps, virtual tours of Silk Road museum holdings across the world, and a host of other pedagogical aids. Thus, although most of the Silkroad Foundation's activities promote the traditional view of the Silk Road as essentially a network of caravan routes extending across Chinese Turkestan, its journal and associated institution, Silk Road Seattle, fosters the study of a Greater Silk Road, one that encompasses roads and routes across the caravan trails and waterways of premodern AfroEurasia-a perspective that is becoming increasingly popular among world historians of the twenty-first century. ${ }^{62}$ In his lengthy

59 The Silkroad Foundation's website is at http://www.silkroadfoundation.org/toc/ index.html. Accessed January 26, 2014.

${ }^{60}$ Silk Road House's website is at www.silkroadhouse.org. Accessed January 26, 2014.

${ }^{61}$ The journal's website is at http://www.silkroadfoundation.org/toc/newsletter.html. Accessed January 26, 2014.

62 The volume of recent work reflecting this view is steadily growing. Good examples of the trend are: Xinru Liu, Silk and Religion: An Exploration of Material Life and the Thought of People, AD 600-1200 (Delhi: Oxford University Press, 1998); idem, The Silk Road in World History (Oxford: Oxford University Press, 2010); idem, The Silk Roads. A Brief History with Documents (Boston and New York: Bedford/St. Martin's, 2012); Michel Jacq-Hergoualc'h, The Malay Peninsula: Crossroads of the Maritime Silk Road (100 BCE-1300 CE), trans. Victoria 
review essay on Hyunhee Park's book on Chinese-Islamic interchange in the pre-modern era, Daniel Waugh remarks that Park's focus on the sea routes rather than land routes that connected the Islamic and Chinese worlds is a welcome change in emphasis from "traditional treatments of 'the Silk Roads." 63

In closing, we have to ask ourselves, are the terms "Silk Road," "Silk Roads," and "Silk Routes" valid today, given the expansion of our knowledge and perspectives over the past 137 years since Baron Ferdinand von Richthofen gave life to these terms and concept? This writer's answer is a resounding "Yes!" There is no good reason to abandon these evocative, albeit inexact, terms. History without romance is sterile. Moreover, it is clear that the current institutionalization of Silk Road studies and its expanse on a global scale due to digital technology ensure that we are now in an era of profound advancement in our understanding of the Silk Road. The Silk Road lives on.

Hobson (Leiden: Brill, 2002); Robert Finlay, The Pilgrim Art: Cultures of Porcelain in World History (Berkeley: University of California Press, 2010); Roxann Prazniak, "Siena on the Silk Roads: Ambrogio Lorenzetti and the Mongol Global Century, 1250-1350," Journal of World History 21 (2010): 177-217; Abdul Sheriff, Dhow Cultures of the Indian Ocean: Cosmopolitanism,Commerce, and Islam (New York: Columbia University Press, 2010); Geoffrey C. Gunn, History without Borders: The Making of an Asian World Region, 1000-1800 (Hong Kong: Hong Kong University Press, 2011); Hyunhee Park, Mapping the Chinese and Islamic Worlds: CrossCultural Exchange in Pre-modern Asia (Cambridge and New York: Cambridge University Press, 2012); Elizabeth Ann Pollard, "Indian Spices and Roman 'Magic' in Imperial and Late Antique Indomediterranea," Journal of World History 24 (2013): 1-23; Timothy May, The Mongol Conquests in World History (London: Reaktion Books, 2013).

${ }^{63}$ Daniel C. Waugh, "Expanding Geographic Horizons along the Maritime Silk Road," The Silk Road 13 (2013): 200, at http://www.silkroadfoundation.org/toc/newsletter.html. Accessed January 26, 2014. See note 61 for a reference to Park's book. 